\title{
Innovation of the firm: How to create performance from capability
}

\author{
TRINH THUY ANH \\ HCMC Open University - thuyanh@ou.edu.vn \\ NGUYEN NGOC THONG \\ HCMC Open University - thong.nn@ou.edu.vn
}

\section{ARTICLE INFO}

Article history:

Received:

Sep. 12, 2017

Received in revised form:

Oct. 09,2017

Accepted:

Oct. 25,2017

Keywords:

Innovation capability

Innovation performance

Multiple regression analysis

Learning capability

Networking capability

\section{ABSTRACT}

Based on the competitive advantage theory and resource-based theory of the firm, this paper examines the impact of innovation capacity on innovation performance of the tourism industry. Innovation capability is defined as the firm's ability to reconfigure and develop their resources and organizational capabilities to innovate. Innovation capability is measured by four components: sensing capability (SC), combination capability (CC), networking capability (NC), and learning capability (LC). Innovation performance is achievement or success of innovation made by a firm in accordance with the target, described by the three components: internal performance (IP), commercial performance (CP), and social performance (SP). The results of Multiple Regression Analysis (MRA) applied to a sample of 242 directors and CEOs of travel agents in a list of Ho Chi Minh City Tourism Association (HTA) and Ho Chi Minh City Department of Tourism show that three (SC, CC, NC) among four components (SC, CC, NC, LC) of innovation capabilities have effects on innovation performance. However, the application of fuzzy set theory in the fuzzy-set qualitative comparative analysis indicates that learning capability does not have any impact on firms' innovation performance. A combination of learning capability and networking capability, nevertheless, creates sufficient conditions for innovation performance. 


\section{Introduction}

Innovation is defined as an economically and socially successful introduction of a new way or a new combination of existing ways of transforming inputs into outputs that result in changes in the value/price relationship offered to the users (De Meyer \& Garg, 2005; Fontana, 2011; Kafetzopoulos \& Psomas, 2012; Aryanto et al., 2015). Innovation could be expressed in terms of product innovation, process innovations, innovation in business model, organizational structure, brand, marketing, management systems, customer service and experience (Davila et al., 2006; Trott, 2008; Fontana, 2011; Aryanto et al., 2015; Keeley et al., 2013).

Suarez-Villa (1990) for the first time introduced innovation capacity as a level of invention and innovative potential at any time or between different locations. Innovation capability is important at all stages of firm development and is needed to address challenges faced by the firm (De Meyer \& Garg, 2005; Fontana, 2011). Innovation capability of firm was studied in many researches (Madanmohan, 2003; Lawson \& Samson, 2001) and the relationship between some parts of innovation capability and overall performance of the firm has been found (Richard et al., 2011; Kafetzopoulos \& Psoma, 2012; Saunila et al., 2014; Nham et al., 2015; Aryanto et al., 2015). Those studies focused on clarifying the relationship between a component of the innovation capability and a component of innovation performance (Antonio et al., 2010, Antonio \& Wiliam, 2015). The relationship between the whole innovation capability and the whole innovation performance has not yet evaluated. This paper aims to fill this gap.

Vietnam's tourism industry has grown fast in recent years (VNAT, 2016). In 2016, Viet Nam welcomed more than 10 million international tourists, 62 million domestic tourists and the total value of 400,000 billion VND revenue. Tourism is a potential economy, not only bring direct revenue from the service sector such as hotels, tours, and attractions, but also promote the development of other related sectors such as transport, dining, entertainment, commercial and some other ancillary services (communications, banks). The total contribution of tourism to the GDP of Vietnam, including direct contributions and indirect public investment is more than US \$ 29 million (13.9\% of GDP). However, the number of international visitors to Vietnam and income from tourism is low, is not commensurate with the potential and desire. From 2007 to now, Vietnam always ranks lower than some countries in the region such as Malaysia, Thailand, Singapore, Indonesia and China (VNAT, 2016). Vietnam's tourism sector still exists many barriers: lack of cohesion, the quality of services, infrastructure, etc. Also, this is a field economy with competitive pressure and rapid speed of change. Currently, Vietnam has more than 4500 travel companies (VNAT, 2016).

Most of researches on the world about innovation capability focus on industry field. In recent years, innovation capability still a new research topic in Vietnam, and there is no research on tourism. However, the rapid growth of technology, environmental change, the instability of the market are factors that require enterprises to evaluate their innovation capabilities special in the field of tourism (WTTC, 2016). What is the capability of tourism companies in Vietnam to make an innovation? What is the performance of tourism companies after delivering an innovation project? How will innovation capability affect to innovation performance in tourism companies? This study aims to seek the answer to these questions.

The main objective of this study is to investigate the influence of tourism company's 
innovation capabilities will also affect to its innovation performance. The context of this study is the rapid development of technology, changes in business models and high levels of global competition that demands continuous innovation. The data of the study was gathered from a sample of 242 directors or CEO of travel companies in Ho Chi Minh City.

\section{Literature review}

\subsection{Competitive advantage theory, resource-based theory and innovation}

According to Porter (1985), competitive advantage is the leverage that a business has over its competitors. Competitive advantage can be gained by offering clients with value, rare, inimitable and non-substitutable, called VRIN (Eisenhardt \& Martin, 2000). Target markets recognize these unique products or services. Competition theory is based on the difference that competitive advantage of firms in the same industry often cannot last long because they are easily copied by competitors or marketed in the first place (Porter, 1985). The competition theory focus on analyzing the role of the environment in the business performance of the business, focusing on environmental impacts rather than idiosyncratic firm attributes on the competitive position of the business. Resource-based theory of business (Wernerfelt, 1984) focuses on competitive analysis based on internal factors resources - of the business. Resource-based theory is expanding in the market and forms the competitive advantage and business performance of the firm.

According to Fontana (2011), innovation aims to make competitive advantage of firms even with external factors or internal factors. In terms of competitiveness, innovation help the firms depends on sustaining a pattern of continuous change in the company and the ways in which that offering is created and delivered, that called innovation. Innovation capability is the internal factor to create competitive advantage in order to achieve business performance of firms (Gamal, 2011).

\subsection{Innovation capability and innovation performance}

Madanmohan (2003) has considered the framework for analysing innovation capability of firm which were including sensing capability, combination capability and relationship capability. Lawson and Samson (2001) have developed innovation capability in organizations by dynamic capabilities approach. Lin et al. (2016) evaluate the affect of dynamic capability on management innovation. Tseng and Lee (2014) have evaluated the effect of dynamic capability on organizational performance; and this was emphasized by Lopez-Cabrales et al. (2016) when they evaluated the role of dynamics in an organization. Dynamic capabilities includes integration capability, learning capability and reconfiguration capability (Wang \& Ahmed, 2007). Integration capability was considered as the capability of collecting and analyzing data from the market; and reconfiguration capability was considered as the capability to response to the market. Both of those capabilities could help the firm to sense about the market, support the firm to build a sensing capability in innovation capability. Chiu et al. (2013) have found the relationship between four types of dynamic capabilities (sensing, coordination, autonomy and reconfiguration capabilities) and radical innovation performance in established firms. Meanwhile, the concept of innovation capability is more widen and reflect organizational capability exactivelly than the concept of dynamic capability, because it mentioned to networking and combination capability which is not included in dynamic 
capability.

There have been some authors who was evaluating the relationship between the components of the innovation capability and organizational performance (Richard et al., 2011; Kafetzopoulos \& Psoma, 2012; Saunila et al., 2014; Nham et al., 2015). Aryanto et al. (2015) proved that strategic human resource management significantly affects innovation capability and furthermore the innovation capability also significantly affects to organizational performance. The organizational performance was considered as an overall performance of the firm, not specified as any part such as internal performance, social performance, commercial performance.

Antonio et al. (2010) have found the relationship between combination and networking capability and innovation performance. While Zahra and George (2002) have studied on absorptive capability which is relevant to sensing and learning capability; and Antonio and Wiliam (2015) have found the effect of absortive capacity and innovation performance. Above previous studies often focused on clarifying the relationship between a components of the innovation capability and a component of innovation performance. The relationship between the whole innovation capability and the whole innovation performance have not yet evaluated.

\section{Innovation capability}

Companies need to satisfy the demand for innovation to meet market demand, create new demands for the market and adapt to the development of the technology. Antonio et al. (2010) explains that companies should be able to extend the life cycle of their products on the market or to create a new product with innovation. Companies need to maintain innovation capabilities in order to survive and grow as well as (Davila et al., 2006; Trott, 2008;
Crossan \& Apaydin, 2010). Skarzynski and Gibson (2008) estimated that in order to get a good performance innovation companies need to have the ability to innovate. The same opinion was also Davila et al. (2006) agree, whereby the need for businesses to develop creative abilities based on positive behaviors, capabilities, and motivation of the rank and staff managed to get a good innovation. And in the opinion of Lawson and Samson (2001) innovation capacity of the company is its ability to convert knowledge and ideas into new products, new processes for the benefit of the company and the stakeholders of it. Madanmohan (2003) defines innovation capacity as the company's ability to form and develop their resources as well as the ability to organize for innovation. Based on Madanmohan (2003), Lawson and Samson (2001), Lin et al. (2016), Wang and Ahmed (2007), Chiu et al. (2013), there are four dimensions of innovation capacity: sensing capability, combination capability, networking capability and learning capability.

\section{Innovation performance}

The innovation performance achievement or success of innovation is done by a company with a suitable target (Wang \& Lin, 2012; Fontana, 2011; Aryanto et al., 2015). Innovation performance can be measured by approaches range from technical, financial and non-financial (Gamal, 2011). OSLO Manual developed by the OECD (2005) described some aspects that can be used to measure the innovation performance in the form of the output of innovation (e.g. number of new products produced, improve quality of the work) and impact of innovation (examples: changes in competition, market expansion, increased productivity, profit, and environmental impact). Based on De Meyer and Garg (2005) and Fontana (2011), innovation performance was described as (i) internal performance, (ii) social performance, (iii) commercial performance. 


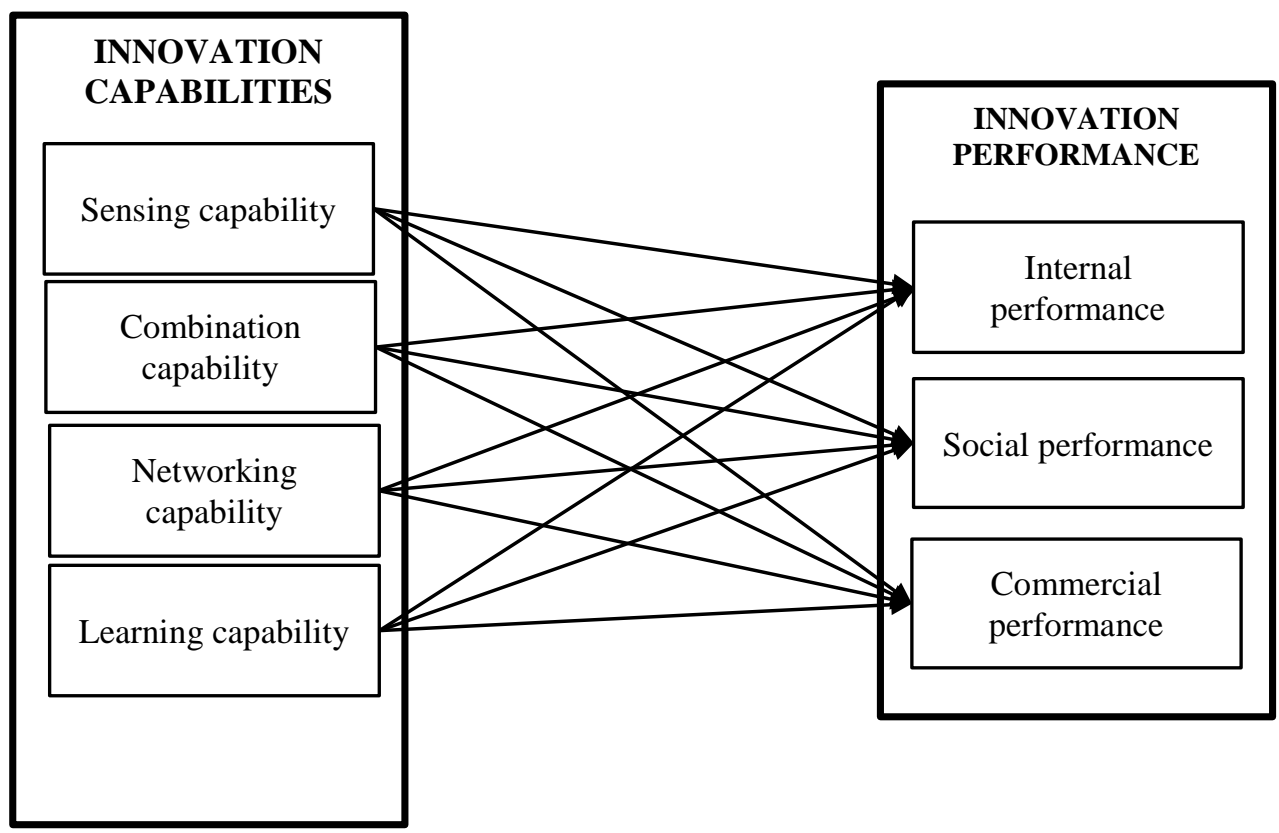

Figure 1. Research model

\subsection{The research model}

Base on previous studies (Antonio et al., 2010; Richard et al., 2011; Kafetzopoulos \& Psoma, 2012; Saunila et al., 2014; Nham et al., 2015; Aryanto et al., 2015, Antonio \& Wiliam, 2015), this paper aim to identify the relationship between innovation capability (measuring as sensing capability, combination capability, networking capability and learning capability) and innovation performance (measuring as internal performance, social performance, commercial performance)

$H_{1.1}$ : Sensing capability has positive effect on internal performance

$H_{1.2}$ : Combination capability has positive effect on internal performance

$H_{1.3}$ : Networking capability has positive effect on internal performance

$H_{1.4}$ : Learning capability has positive effect on internal performance
$H_{2.1}$ : Sensing capability has positive effect on social performance

$H_{2.2}$ : Combination capability has positive effect on social performance

$H_{2.3}$ : Networking capability has positive effect on social performance

$H_{2.4}$ : Learning capability has positive effect on social performance

$H_{3.1}$ : Sensing capability has positive effect on commercial performance

$H_{3.2}$ : Combination capability has positive effect on commercial performance

$H_{3.3}$ : Networking capability has positive effect on commercial performance

$H_{3.4}$ : Learning capability has positive effect on commercial performance

The basis of the framework is the idea that companies have to concentrate on developing the four aspects of innovation capability in order to achieve higher innovation performance. The findings of the study thus test the relationship 
between innovation capability and innovation performance with the better theoretical background.

\section{Methodology}

\subsection{Measurement}

\subsubsection{Sensing capability (SC)}

SC rated capacity of the company felt the need for innovation. It assessed using a 5 items scale based on content: scan the environmental changes to identify new business opportunities, review on how environmental changes influence on customer, review our products to reassure that they fulfill customer demand, efforts on the functions new and existing products (Tseng \& Lee, 2014); and implementing ideas for new products and improving existing products (Lopez-Cabrales et al., 2016).

\subsubsection{Combination capability (CC)}

$\mathrm{CC}$ includes the items representing the ability to search, select and synthesize many different sources of information as the basis for innovation of company as customers, suppliers, competitors, employees in the company, professional organizations, and the company encourages employees to have teamwork when improvement/innovation (Aryanto et al., 2015).

\subsubsection{Networking capability (NC)}

The research of Lin et al. (2015) showed as $\mathrm{NC}$ includes a set of items related to connectivity, the interaction between the members of the company that motivates innovation, and also a leadership culture that facilitates innovation. Based on these, the content of items focused the support of the whole organization, progressed as planned, managers participate, acquired the opinions of consultants and industry experts, employees feedback.

\subsubsection{Learning capability (LC)}

LC includes the items that measure selflearning of the members of the organization, the environment encourages the exchange and enhance knowledge, the process of receiving and distributing knowledge (Lopez-Cabrales et al., 2016). Contents of items are: people here receive support and encouragement when presenting new ideas, people feel encouraged to generate new ideas, people are encouraged to take risks in organization, systems, and procedures for receiving, collating and sharing information from outside the company, to collect, bring back, and report information about what is going on outside the company.

\subsubsection{Internal performance (IP)}

IP comprises five items. This factor includes a set of efficiency manifestations related to the internal operations of companies such as satisfaction, positive and proactive employees, growing productivity, etc. (Aryanto et al., 2015). The content of items are: has more satisfied employees; has more creative and innovative employees; growing productivity of employees; employees always propose to be new ideas to solve problems, performance of company has improved greatly through the innovative ideas of its members in recent years (Aryanto et al., 2015).

\subsubsection{Social performance (SP)}

SP includes the items that represent the operating effectiveness of community connections, build corporate image. (Aryanto et al., 2015). Based on this result, items focused on: customers increasingly sympathetic to the company's brand, company's information is shared on social networking, quality of employees applying for a growing company", easily find information about the company on the 
Internet, most customers have positive feedback after using our company's services.

\subsubsection{Commercial performance $(C P)$}

$\mathrm{CP}$ includes the items representing the ability to search, select and synthesize many different sources of information as the basis for innovation of company (Tseng and Lee, 2014), that customers can access information about the company through the smart devices, social networks, websites and so on ... (Lopez-Cabrales et al., 2016) grasp the right timing for launching new products or services, ability to develop highquality new products, launch speed of new products is faster than other companies (Tseng \& Lee, 2014).

\subsection{Sample and data collection}

The approach of this study is quantitative. The questionnaire developed for the study consists of three major parts. The first part comprises 20 items measuring different issues related to innovation capability, divided into four sub categories including sensing capability (SC), combination capability (CC), networking capability (NC) and learning capability (LC) (Madanmohan, 2003; Antonio, 2012). The second part comprises three sub categories measuring innovation performance with internal performance (IP), social performance (SP) and commercial performance (CP) (De Meyer \& Garg, 2005; Fontana, 2011) with 15 items.

A seven-point Likert-type scale measured each of these variables, ranging from 1 (strongly disagree) to 7 (strongly agree). These items modified from studies by De Meyer and Garg (2005); Fontana (2011); Tseng and Lee (2014); Aryanto et al. (2015).

The data of the study was gathered from a sample of 242 directors or CEO of travel companies in Ho Chi Minh City. Sampling methods were conducted by sending questionnaires to each participant at two conferences in Ho Chi Minh City whose is the company operating in the tourism sector. Two conferences took place in Ho Chi Minh City in July 2017. First, "Electronic Tourism" conference (July 5, 2017) by the E-commerce and Information Technology Agency in coordination with Viet Nam National Administration of Tourism. This has 600 delegates from more than 300 enterprises provide online travel services, accommodation, travel, restaurants, tourist resorts, information technology companies, payment, marketing. Second, "Introduction to New Destinations in Chungcheongbuk-do, Chungcheongnam-do, Daejeon and Sejong, South Korea (July 19, 2017) by the Korea Tourism Organization (KTO) with 200 delegates from 78 enterprises. The research team was introduced by Vietravel Company (a reputable company in the travel industry), so the team is very convenient in interviewing, data collection. A total of 300 questionnaires were sent and 290 questionnaires were recovered. 48 questionnaires have excluded because of lack of information, the remaining 242 questionnaires were used to analyze (81\% of the total questionnaires).

\section{Results and discussion}

The age of respondents is generally between 30 and 40 years. The proportion of men and women participating in the questionnaire was well balanced. All are working in the management position (director or vice director) with years of experience in management activities mainly 2-4 years and 4-10 years. Regarding organizational size based on the number of employees, 82 percent of the respondents came from very small firms with 49 employees or less, and around 18 percent were from small firms with 50 employees or more. 
Based on revenue, around 48 percent of the respondents were from companies with 2-5 billion VND revenue of year, around 42 percent from firms with 5-20 billion VNĐ revenue of year, and around 10 percent of businesses with 20-50 billion NVĐ revenue of year. Most respondents provide services to both domestic customers and international customers $(90 \%)$.

\section{Table 1}

Characteristics of respondents

\begin{tabular}{lll}
\hline Age & $30 \%$ & under 30 years \\
& $45 \%$ & $30-40$ years \\
& $20 \%$ & $40-50$ years \\
& $5 \%$ & over 50 years \\
\hline Sex & $55 \%$ & Male \\
& $45 \%$ & Female \\
\hline Position & $47 \%$ & Director \\
& $50 \%$ & Vice- Director \\
& $3 \%$ & Other \\
\hline Management & $10 \%$ & $1-2$ years \\
experience & $50 \%$ & $2-4$ years \\
& $30 \%$ & $4-10$ years \\
& $10 \%$ & Over 10 years \\
\hline Size Company & $82 \%$ & 49 employees or less \\
& $18 \%$ & 50 employes or more \\
\hline Revenue & $48 \%$ & $2-5$ bilion VND/year \\
& $42 \%$ & $5-20$ bilion VND/year \\
& $10 \%$ & 20 bilion VND/year or more \\
\hline Market & $90 \%$ & Domestic and International Customer \\
& $10 \%$ & Only Domestic or International customer \\
\hline $45 \%$ & Restaurants and Hotels \\
& $35 \%$ & Travel services \\
& $20 \%$ & Other \\
\hline & & \\
& & \\
& &
\end{tabular}

Table 2 presents the means, standard deviations (SD) of the variables used in this study. The means of all items closed to 5.66 which is the median on a seven-point scale (1strongly disagree; 7 -strongly agree). This result shows that the level of respondents agreed on the content found on average and tended to shift to the right. The reason for this may be explained as the Vietnamese tend to deviate to the right (fully agree) when answering the question with the Likert scale (Tho \& Trang, 2015). This result shows that the degree of consensus from 
respondents for the content of items aspects is above average. The standard deviation value is approximately from 0.841 to 1.444 , which demonstrates the concensus of the interviewees. Previously, factor analysis result show four components of innovation capability including sensing capability, combination capability, networking capability and learning capability have 15 items $(\mathrm{KMO}=0.896$; Bartlett test $=$ 0.000 ; Communality $>0.5$; Total variance $=$ 77.18 percent). Likewise, the factor analysis of innovation performance, which gives as a result three components with 14 items $(\mathrm{KMO}=0.863$; Bartlett test $=0.000$; Communality $>0.5$; Total variance $=72.16$ percent $)$.

\section{Table 2}

Descriptive and confirmatory factor analysis results

\begin{tabular}{|c|c|c|c|c|c|c|c|}
\hline & Items & Mean & SD & $\begin{array}{c}\text { Standard } \\
\text { lambda }\end{array}$ & $\begin{array}{c}\text { Cronbach's } \\
\text { Alpha }\end{array}$ & AVE & $\lambda$ \\
\hline \multirow{3}{*}{$\begin{array}{c}\text { Sensing } \\
\text { Capability }\end{array}$} & $\begin{array}{l}\text { We frequently scan } \\
\text { the environmental } \\
\text { changes to identify } \\
\text { new business } \\
\text { opportunities }\end{array}$ & 5.741 & 1.123 & 0.633 & \multirow{3}{*}{0.863} & \multirow{3}{*}{0.472} & 0.57 \\
\hline & $\begin{array}{l}\text { We periodically } \\
\text { review on how } \\
\text { environmental } \\
\text { changes influence on } \\
\text { customer }\end{array}$ & 6.032 & 1.135 & 0.736 & & & 0.58 \\
\hline & $\begin{array}{l}\text { We frequently review } \\
\text { our products to } \\
\text { reassure that they } \\
\text { fulfill our customer } \\
\text { demand }\end{array}$ & 5.372 & 0.841 & 0.715 & & & 0.62 \\
\hline
\end{tabular}

Combination Capability
We innovate based on the opinions / information contributions from customers, suppliers, competitors

We innovate based on the opinions / information 5.308 1.188 0.667 0.66 $\begin{array}{llll}6.072 & 1.138 & 0.732 & 0.61\end{array}$

$0.793 \quad 0.572$

contributions of employees in the 


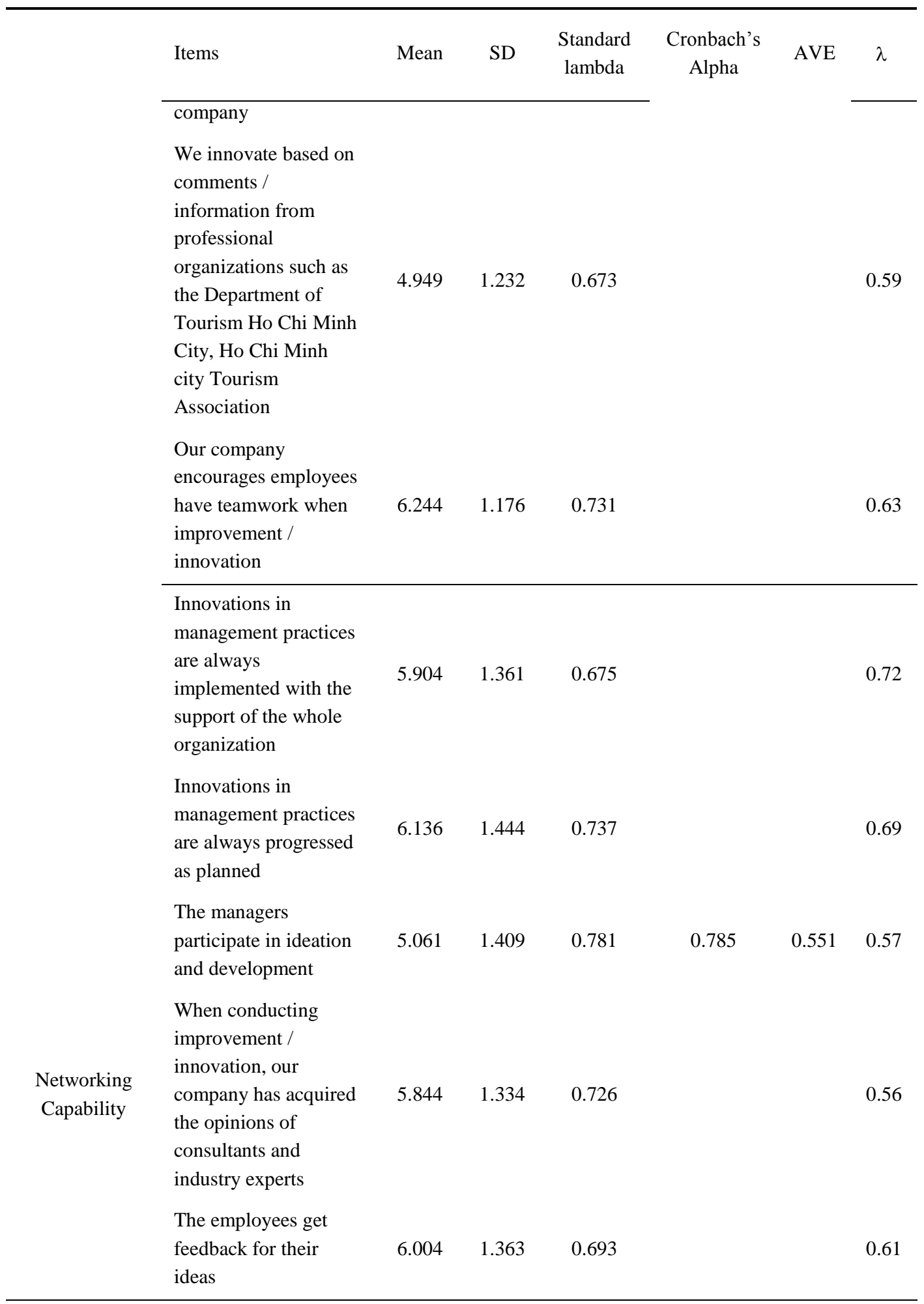




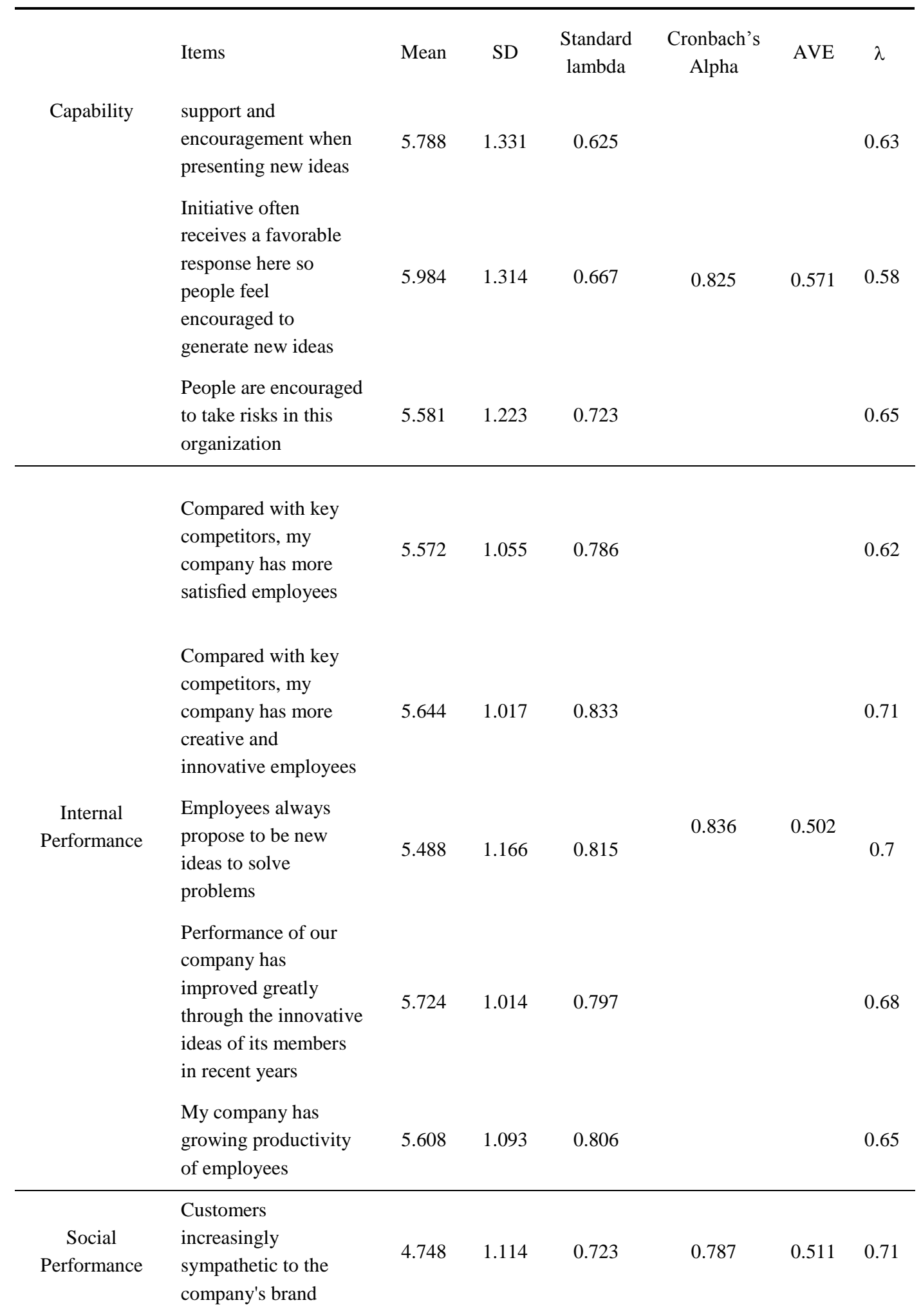




\begin{tabular}{|c|c|c|c|c|c|c|c|}
\hline & Items & Mean & SD & $\begin{array}{c}\text { Standard } \\
\text { lambda }\end{array}$ & $\begin{array}{c}\text { Cronbach's } \\
\text { Alpha }\end{array}$ & AVE & $\lambda$ \\
\hline & $\begin{array}{l}\text { Information our } \\
\text { company is shared on } \\
\text { social networking }\end{array}$ & 5.684 & 1.083 & 0.671 & & & 0.67 \\
\hline & $\begin{array}{l}\text { The quality of } \\
\text { employees applying } \\
\text { for a growing } \\
\text { company }\end{array}$ & 5.692 & 1.078 & 0.722 & & & 0.68 \\
\hline & $\begin{array}{l}\text { Easily find } \\
\text { information about our } \\
\text { company on the } \\
\text { Internet }\end{array}$ & 5.448 & 1.172 & 0.699 & & & 0.59 \\
\hline & $\begin{array}{l}\text { Most customers have } \\
\text { positive feedback after } \\
\text { using our company's } \\
\text { services }\end{array}$ & 5.932 & 0.999 & 0.705 & & & 0.63 \\
\hline \multirow{4}{*}{$\begin{array}{l}\text { Commercial } \\
\text { Performance }\end{array}$} & $\begin{array}{l}\text { Our company is able } \\
\text { to grasp the right } \\
\text { timing for launching } \\
\text { new products or } \\
\text { services }\end{array}$ & 5.084 & 1.247 & 0.735 & \multirow{4}{*}{0.796} & \multirow[b]{2}{*}{0.589} & 0.66 \\
\hline & $\begin{array}{l}\text { Customers can access } \\
\text { information about our } \\
\text { company through the } \\
\text { smart devices, social } \\
\text { networks, websites } \\
\text { and so on ... }\end{array}$ & 6.036 & 1.197 & 0.787 & & & 0.58 \\
\hline & $\begin{array}{l}\text { Our company is } \\
\text { equipped with the } \\
\text { ability to develop } \\
\text { high-quality new } \\
\text { products }\end{array}$ & 5.264 & 1.219 & 0.702 & & & 0.59 \\
\hline & $\begin{array}{l}\text { The launch speed of } \\
\text { new products is faster } \\
\text { than other companies } \\
\text { in the same industry }\end{array}$ & 6.196 & 1.194 & 0.812 & & & 0.63 \\
\hline
\end{tabular}


First, a confirmatory analysis of first order is carried out with the constructs' factors affecting innovation performance, which show optimum results. So, the standardized lambda coefficients are higher than 0.5 in every case, which denotes acceptable convergent validity (Steemkamp and Van Trijp, 1991). To test discriminant validity, we followed the procedure described by Anderson and Gerbing (1998), in which the confidence intervals for the correlation of the constructs were estimated and compared with unity. In none of the cases did the intervals contain the value 1 . As a result, the proposed measurement model is an acceptable fit.

To assess the reliability of the constructs, Cronbach's alpha and the average of variance extracted (AVE) were used (Table 2). After testing the validity of the scale, the reliability and validity of every construct in the causal model are analyzed using a confirmatory analysis. The proposed model is correct (Table 2), since all second-order latent variables have inner strength, as it is shown by the Cronbach's alpha values and the AVE coefficient, close or higher than 0.7 and 0.5 , respectively. Standardised coefficients are all of them significant and greater than value 0.5 , guaranteeing the convergent validity in every dimension.

Table 3 presents the correlation between the factors in the model, and the results show that there are correlations among the factors.

\section{Table 3}

Correlation of factors

\begin{tabular}{|c|c|c|c|c|c|c|}
\hline & $\begin{array}{l}\text { Combination } \\
\text { Capability }\end{array}$ & $\begin{array}{l}\text { Networking } \\
\text { Capability }\end{array}$ & $\begin{array}{l}\text { Learning } \\
\text { Capability }\end{array}$ & $\begin{array}{l}\text { Internal } \\
\text { Performance }\end{array}$ & $\begin{array}{l}\text { Social } \\
\text { Performance }\end{array}$ & $\begin{array}{l}\text { Commercial } \\
\text { Performance }\end{array}$ \\
\hline $\begin{array}{l}\text { Sensing } \\
\text { Capability }\end{array}$ & 0.15 & 0.11 & 0.16 & 0.65 & 0.59 & 0.63 \\
\hline $\begin{array}{l}\text { Combination } \\
\text { Capability }\end{array}$ & 1 & 0.17 & 0.10 & 0.61 & 0.55 & 0.65 \\
\hline $\begin{array}{l}\text { Networking } \\
\text { Capability }\end{array}$ & - & 1 & 0.22 & 0.69 & 0.54 & 0.59 \\
\hline $\begin{array}{l}\text { Learning } \\
\text { Capability }\end{array}$ & - & - & 1 & 0.42 & 0.38 & 0.66 \\
\hline $\begin{array}{l}\text { Internal } \\
\text { Performance }\end{array}$ & - & - & - & 1 & 0.17 & 0.23 \\
\hline $\begin{array}{l}\text { Social } \\
\text { Performance }\end{array}$ & - & - & - & - & 1 & 0.22 \\
\hline $\begin{array}{l}\text { Commercial } \\
\text { Performance }\end{array}$ & - & - & - & - & - & 1 \\
\hline
\end{tabular}

The Confirmatory Factor Analysis (CFA) method is used to evaluate the scale. The critical model is built through a combination of business results measures and components of innovation capabilities and components of innovation performance. The CFA results show that the 
model has acceptable compatibility: $\chi^{2}{ }_{[240]}=$ $463.70(\mathrm{p}=0.000)$; GFI $=0.863$; CFI $=0.927$ and RMSEA $=0.058$. The results also show that the CFA weights of all observed variables are large (at least 0.56), confirming the uniqueness and convergence values of components of innovation capability and innovation performance. The results also show that the correlation coefficients of the concepts are smaller than the unit, confirming the difference between the concepts. The scales meet the requirement for total reliability $(\mathrm{pc} \geq 0.74)$ and extrapolation deviation $(\geq 0.50)$

This study uses the interview method with one survey participant (one respondent and at the same time). Therefore, the ability to deviate due to the Common Method Bias (CMB) method may be present. To test this deviation, the study used the Harman test with CFA and the unmeasured latent variable (Markel \& Frone, 1998). The results show that the fit of the single factor model $\left[\chi_{[120]}^{2}=1507.16(\mathrm{p}=0.000) ; \mathrm{GFI}\right.$ $=0.566 ; \mathrm{CFI}=0.588$ and RMSEA $=0.168]$ are far from the multifactor model $\left[\chi_{[122]}^{2}=345.60\right.$ $(\mathrm{p}=0.000) ; \mathrm{GFI}=0.756 ; \mathrm{CFI}=0.931$ and RMSEA $=0.068]$. The results with dummy latent variables also show that the weightings of the variables that measure the study concepts change insignificantly and that these weights on the dummy variables are small and not statistically significant ( $p>0.05$ ). Therefore, the CMB, if any, does not distort the results of the study.

Multiple regression analysis (MRA) and fuzzy-set qualitative comparative analysis (fsQCA) are used to test the hypothesis. Table 4 shows the results of MRA. Note that research concepts are measured with a scale that includes a variety of measurement variables. Thus, in MRA result, the average variable (mean of the variables that measure the study concepts) is used because the scale of the research concepts is unidimensionality. The MRA results show that learning capability has no impact on two (internal performance, social performance) of three components of innovation performance (Sig>0.05). Other components of innovation capability (sensing capability, combination capability, networking capability has effects on innovation performance including internal performance, social performance and commercial performance.

\section{Table 4}

MRA results for innovation capabilities and innovation performances

\begin{tabular}{|c|c|c|c|c|c|c|c|c|}
\hline \multirow{3}{*}{ Dependent variable } & \multicolumn{8}{|c|}{ Independent Variables } \\
\hline & \multicolumn{2}{|c|}{$\mathrm{SC}$} & \multicolumn{2}{|c|}{$\mathrm{CC}$} & \multicolumn{2}{|c|}{$\mathrm{NC}$} & \multicolumn{2}{|c|}{$\mathrm{LC}$} \\
\hline & $\beta$ & Sig & $\beta$ & Sig & $\beta$ & Sig & $\beta$ & Sig \\
\hline \multirow{2}{*}{$\begin{array}{l}\text { Internal Performance } \\
\text { (Model 1) }\end{array}$} & 0.38 & 0.00 & 0.30 & 0.01 & 0.32 & 0.00 & -0.08 & 0.26 \\
\hline & \multicolumn{2}{|c|}{$\mathrm{H}_{1.1}$ accepted } & \multicolumn{2}{|c|}{$\mathrm{H}_{1.2}$ accepted } & \multicolumn{2}{|c|}{$\mathrm{H}_{1.3}$ accepted } & \multicolumn{2}{|c|}{$\mathrm{H}_{1.4}$ rejected } \\
\hline Social Performance & 0.32 & 0.00 & 0.27 & 0.00 & 0.23 & 0.00 & -0.11 & 0.32 \\
\hline (Model 2) & \multicolumn{2}{|c|}{$\mathrm{H}_{2.1}$ accepted } & \multicolumn{2}{|c|}{$\mathrm{H}_{2.2}$ accepted } & \multicolumn{2}{|c|}{$\mathrm{H}_{2.3}$ accepted } & \multicolumn{2}{|c|}{$\mathrm{H}_{2.4}$ rejected } \\
\hline Commercial Performance & 0.35 & 0.04 & 0.26 & 0.00 & 0.41 & 0.00 & 0.12 & 0.02 \\
\hline (Model 3) & \multicolumn{2}{|c|}{$\mathrm{H}_{3.1}$ accepted } & \multicolumn{2}{|c|}{$\mathrm{H}_{3.2}$ accepted } & \multicolumn{2}{|c|}{$\mathrm{H}_{3.3}$ accepted } & \multicolumn{2}{|c|}{$\mathrm{H}_{3.4}$ accepted } \\
\hline
\end{tabular}


For model 1, the influence of the independent variables sensing capability (SC), networking capability (NC), combination capapbility (CC) on the dependent variable internal performance (IP). Furthermore, the variable inflation factors (VIF) for all structures ranged from 2.65 to 3.67 , lower than the ten thresholds. This suggests that there are not multicollinear, so all the correlation between factors will not confuse the results of the subsequent statistical tests (Newbert, 2008). Sensing capability most influential to internal performance $($ Beta $=0.38$, Sig. $=0.00)$, next is networking capability $($ Beta $=0.32$, Sig. $=0.00)$ and combination capability (Beta $=0.30$, Sig. $=$ $0.01)$. Learning capability has not affected to internal performance (Sig. $=0.26>0.05$ ). This result shows employee's self-learning, the environment and learning policy in companies still not good. In fact, very few companies organize intensive training programs for employees. Most of them only participate in the training program of Travel Association Ho Chi Minh City or Tourism Department Ho Chi Minh City. Training content focuses mainly on professional skill and products development. Employees do not have a chance to improve their self-learning.

Model 2 also shows similar results when the social performance influenced by sensing capability $($ Beta $=0.32$, Sig. $=0.00)$, combination capability $($ Beta $=0.27$, Sig. $=$ 0.00 ), networking capability (Beta $=0.23$, Sig. $=$ 0.00 ). Learning capacity of travel companies is not a factor affecting the success of social aspects of travel companies which including developing the social image, attract good employees, information of companies on social networks, etc. Normaly, travel companies (especially SMEs) have not focused on building a learning capacity of their staffs. Tourism companies have organize training activities but for improving their business only, which is focused on upgrade quality service, market expansion, understanding customer needs. Their training course is not focus on sustainable development as improve organizational competency, competitive advantage, corporate social responsibility.

Model 3 shows that all three independent variables have an impact on the dependent variable (Sig. <0.05), in which the most influential networking capability (Beta $=0.41$, Sig. $=0.00$ ), the next is sensing capability (Beta $=0.35$, Sig. $=0.04)$, combination capability $($ Beta $=0.26$, Sig. $=0.00)$ and learning capability $($ Beta $=0.12$, Sig. $=0.02)$. This result proved to improve commercial performance in the tourism sector, the ability of the company to establish a network of relationships, connect with partners, sensing and changing needs of the market is the most important. Especially, learning activities in tourism companies focus on commercial performance.

To apply fsQCA test the hypothesis, data collected from Likert scale 1 to 7 is converted to fsQCA data from 0 to 1 (Ragin, 2008). This transformation is realized through a combination of three methods: scale based (7 point Likert, Ordanini \& cs, 2014), based on data (Woolside, 2013), based on market context (Tho \& Trang, 2015). As a result, the three qualitative anchors for conversion are the full membership threshold of 6.5; the full non-membership threshold is 3 and the crossover point is 4.5 (over 7 points on the Likert scale).

Based on Ragin (2008), this study choses a consistency threshold of 0.85 . Results from fsQCA 2.5 software with a cutoff value of 0.85 (consistent limits, Table 5) show answer parsimonious solution. Specifically, social capability, combination capability are two conditions that are sufficient for innovation performance (including internal performance, social performance, and commercial 
performance) to exist (Table 5). However, conditions for innovation performance. networking capability is not a sufficient condition for Innovation Performance, as in MRA results, which incorporates the learning capability component to create sufficient

$S C+C C+N C * L C=>$ Internal Performance $S C+C C+N C * L C=>$ Social Performance $S C+C C+N C * L C=>$ Commercial Performance

\section{Table 5}

Fuzzy-set qualitative comparative analysis result

\begin{tabular}{|c|c|c|c|}
\hline \multicolumn{4}{|l|}{ Answer: Parsimonious solution } \\
\hline \multicolumn{4}{|l|}{ Internal Performance $=\mathrm{f}(\mathrm{SC}, \mathrm{CC}, \mathrm{NC}, \mathrm{LC})$} \\
\hline \multicolumn{4}{|l|}{ Frequency Cutoff: 2.000000} \\
\hline \multicolumn{4}{|l|}{ Consistency Threshold: 0.8521785} \\
\hline \multirow[b]{2}{*}{ Independent Variables } & \multicolumn{2}{|l|}{ Converage } & \multirow[t]{2}{*}{ Consistency } \\
\hline & Raw & Unique & \\
\hline Sensing Capability & 0.873092 & 0.069990 & 0.735751 \\
\hline Combination Capability & 0.799772 & 0.026957 & 0.772367 \\
\hline Networking Capability*Learning Capability & 0.697304 & 0.013316 & 0.817049 \\
\hline
\end{tabular}

Solution coverage: 0.930172

Solution consistency: 0.700031

Answer: Parsimonious solution

Social Performance $=\mathrm{f}(\mathrm{SC}, \mathrm{CC}, \mathrm{NC}, \mathrm{LC})$

Frequency Cutoff: 2.000000

Consistency Threshold: 0.8517863

\begin{tabular}{l|l|l|l}
\hline \multirow{2}{*}{ Independent Variables } & \multicolumn{2}{|l|}{ Converage } & \multirow{2}{*}{ Consistency } \\
\cline { 2 - 3 } & Raw & Unique & \\
\hline Sensing Capability & 0.748632 & 0.001105 & 0.825199 \\
\hline Combination Capability & 0.758088 & 0.001540 & 0.829219 \\
\hline Networking Capability*Learning Capability & 0.825421 & 0.002679 & 0.806729 \\
\hline
\end{tabular}

Solution coverage: 0.921172

Solution consistency: 0.7000135

Answer: Parsimonious solution

Commercial Performance $=\mathrm{f}(\mathrm{SC}, \mathrm{CC}, \mathrm{NC}, \mathrm{LC})$

Frequency Cutoff: 2.000000

Consistency Threshold: 0.853665 


\begin{tabular}{l|l|l|l}
\hline \multirow{2}{*}{ Independent Variables } & \multicolumn{2}{|l|}{ Converage } & \multirow{2}{*}{ Consistency } \\
\cline { 2 - 3 } & Raw & Unique & \\
\hline Sensing Capability & 0.835600 & 0.000435 & 0.795740 \\
\hline Combination Capability & 0.853212 & 0.002645 & 0.818989 \\
\hline Networking Capability*Learning Capability & 0.825522 & 0.002310 & 0.805693 \\
\hline
\end{tabular}

Solution coverage: 0.913172

Solution consistency: 0.700067

Table 5 shows that the learning capability and networking capability components are INUS (Insufficient but Necessary part of a condition) (Mackie, 1965). They are not sufficient conditions (because they must be combined with other components to create sufficient conditions), but necessary (in combination with other elements) to create sufficient conditions for business results. However, this combination is not a prerequisite because other components are customer response, aggressive response) but are adequate for business results. Thus, MRA helps us to discover the net effect through the value of the beta regression of innovation capability components affecting Innovation Performance of companies, and fsQCA contributes to exploring the complex causal relationship between them. The results suggest that researchers should use a variety of analytical methods in their research to explore the complex relationship between business variables (Ragin, 2008; Woolside, 2013).

The study also investigated the relationship between innovation capability and innovation performance. The findings contribute to the current theory by indicating that all aspects of innovation performance are dependent on the state of innovation capability. This is consistent with major studies on the impact of innovation, such as Madanmohan (2003), Lopez-Cabrales et al. (2016), Antonio et al. (2010), Tseng and Lee
(2014), and Saunila et al. (2014). The positive relationship between innovation capability and innovation performance and most aspects of innovation are included in this study. Based on that, regression analysis has determined the effect of innovation capability on each aspect of innovation performance.

Accordingly, the relationship of innovation capability and innovation performance is as follows: sensing capability, combination capability, and networking capability have a positive influence on all aspects of the innovation performance (including internal performance, social performance, and commercial performance). The fsQCA results indicate that both of these components (networking capability and learning capability) are not sufficient conditions for Innovation Performance, but they combine to create sufficient conditions for Innovation Performance presence (Table 5). This result is consistent with the previous study as De Meyer and Garg (2005), Aryanto et al. (2015). This result shows that level of concern of managers about learning capability enhancement in tourism companies in Viet Nam is small. This will affect the sustainability of businesses because learning capability is a significant factor affecting the competitiveness and performance (Alegre and Chiva, 2008).

From results of this study showed that companies need to seriously reconsider about 
building and improve company's innovation capability through sensing capability, combination capability, networking capability, and learning capability. Sensing capability of tourism companies is good, however it is the most factor to effect innovation performance then tourism companies still needed to improve it more. The tourism companies need to set up a special unit for responsibility of identification of new business opportunity, reviewing the environmental changes and its effect on customer hebavior, discovering the customer insight and reviewing how their product response to customer needs. Moreover, innovation capability should be considered as an organizational capability and then this innovation unit need to set up an approach to improve innovation capability of individual to contribute to organizational capability. Combination capability related to the ability to collect data, information, idea, opinion from many stake holders such as customer, supplier, competitor, state agency, employee, etc. in order to innovate. Due to the high effect of combination capability to performance, the tourism companies should create a network for innovation idea gathering, search and aggregate information from many different sources. Networking capability focus on team work of stake holders to encourage innovation. The tourism companies should open the innovation outside of their firm, called innovation with open system or innovation ecology to mobilize humane resource of the whole society to support for their firm. Learning capability is a key factor for innovation. The tourism companies should have appropriate policy to support and encourage their employee to present and generate new ideas, take risk and learn by experience.

\section{Conclusion}

There have been some authors who was evaluating the relationship between the components of the innovation capability and organizational performance (Richard et al., 2011; Kafetzopoulos \& Psoma, 2012; Saunila et al., 2014; Nham et al., 2015). Aryanto et al. (2015) proved that innovation capability significantly affects to organizational performance which was considered as an overall performance of the firm, not specified as three parts including internal performance, social performance, commercial performance. Some authors found the relationship between some components of innovation capability and a component of innovation performance (Antonio et al., 2010; Zahra \& George, 2002; Antonio \& Wiliam, 2015). The relationship between the whole innovation capability and the whole innovation performance have not yet evaluated.

The study contributes to present the relationship between an overall innovation capability (that consist of sensing capability, combination capability, networking capability and learning capability) and overall innovation performance (that consists of internal performance, social performance, and commercial performance). The study reduces the gap, where most research focuses on analyzing each of the components of innovation capability and innovation performance rather than on a detailed analysis of the relationship between them. This study has found the relationship between innovation capability and innovation performance, in which the components of innovation capability have different influences to every aspect of innovation performance. There is no research on innovation capability and innovation performance in Vietnam, espeacilly no research on tourism industry. This research focus on tourism companies to propose some managerial meaning for them. The hypotheses of 
the research have been tested by MRA and fsQCA to demonstrate the impact of innovation capability on each of the components of innovation performance. The result identifies the problem why learning capability does not affect two among three components of innovation performance (internal performance, social performance). Due to the characteristics of the travel companies in Vietnam, the training course mostly focuses on professional skill, sale and products development. Employees have a few chance to improve their self-learning as well as their knowledge on internal performance and social performance of their companies. However, the learning capability must incorporate with sensing capability, networking capability and combination capability as a whole as a requirement of innovation performance. The research results contribute to better understanding of the role of the innovation capability for innovation performance of the company. From there, these measures for nurturing and building this capacity will help to create a competitive advantage in the market during the integration into the international market. Based on the relationship between innovation capability and innovation performance, companies can choose to develop each component of innovation capacity or develop all in order to improve innovation performance of them. The results of the study provide a good starting point for in-depth studies of the subject. This study has some limitations which should be acknowledged. First, the sample size should be expanded to increase representation, types of companies, type of businesses, operating locations and so on. Second, the measurement of aspects related to innovation capability seems to be rare in SMEs. This problem affects the self-perception of innovation capabilities of each company

\section{References}

Alegre, J., \& Chiva, R. (2008), Assessing the impact of organizational learning capability on product innovation performance: An empirical test. Technovation, 28(6), 315-326.

Aryanto, R., Fontana, A., \& Zakaria A. (2015). Strategic human resource management, innovation capability and performance: An empirical study in Indonesia software industry. Procedia - Social and Behavioral Sciences, $211,874-879$.

Antonio, K. W. L, Tang, E., \& Richard, C. M. Y. (2010), Effects of supplier and customer integration on product innovation and performance: Empirical evidence in Hong Kong Manufacturers. The Journal of Product Innovation Management, 27(5), 761-777.

Antonio, K. W. L., \& William, L. (2015). Regional innovation system, absorptive capacity and innovation performance: An empirical study. Journal of Technological Forecasting and Social Change, 92, 99-114.

Chiu, W. H., Chi, H. R., Chang, Y. C., \& Chen, M. H. (2013). Dynamic capabilities and radical innovation performance in established firms: A structural model. Journal of Technology Analysis \& Strategic Management, 28(8), 965-978.

Crossan, M. M., \& Apaydin, M. (2010). A multi-dimensional framework of organizational innovation: A systematic review of the literature. Journal of Management Studies, 47(6), 1154-1191.

Davila, T., Epstein, M. J., \& Sheldon, R. (2006). Making innovation work. Pearson Education Inc.

De Meyer, A., \& Garg, S. (2005). Inspire to innovate: Management and innovation in Asia. Palgrave Macmillan, New York.

Eisenhardt, K. M., \& Martin, J. A. (2000). Dynamic capabilities: What are they? Strategic Management Journal, 2l(10-11), 1105-1121. 
Fontana, A. (2011). Innovate we can! Innovation management and value creation revision edition. Publisher of Cipta Innovasi Sejahtera, Bekasi, Malaysia.

Gamal, D. (2011). How to measure organization innovativeness? Technology Innovation and Entrepreneurship Center.

Grawe, S. J. (2009). Logistics innovation: A literature-based conceptual framework. International Journal of Logistics Management, 20(3), 360-377.

Kafetzopoulos, D., \& Psomas, E. (2012). The impact of innovation capability on the performance of manufacturing companies: The Greek case. Journal of Manufacturing Technology Management, 26(1), 104130.

Keeley, L., Pikkel, R., Quinn, B., \& Walters, H. (2013). Ten types of innovation: The discipline of building breakthroughs. John Wiley \& Sons, New Jersey.

Lawson, B., \& Samson, D. (2001). Developing innovation capability in organisations: A dynamic capabilities approach. International Journal of Innovation Management, 5(3), 377-400.

Lin, H. Y., Su, J. Q., \& Higgins, A. (2016). How dynamic capabilities affect adoption of management innovations. Journal of Business Research, 69(2), 862-876.

Lopez-Cabrales, A., Bornay-Barrachina, M., \& Diaz-Fernandez, M. (2016). Leadership and dynamic capabilities: The role of HR systems. Personnel Review, 46(2), 255-276.

Mackie, J. L. (1965). Causes and conditions. American Philosophical Quarterly, 2(4), 245-264.

Madanmohan, T (2003). A framework for analysing innovative capability of firms in network industries. Indian Institute of Management Bangalore, Bangalore.

Nham, T., Nguyen, N., Pham, G., \& Nguyen, N. (2015). The effects of innovation on firm performance of supporting industries in Hanoi, Vietnam. Journal of Industrial Engineering and Management, 9(2).

OECD. (2005). Oslo manual the measurement of scientific and technological innovations. OECD, Paris.

Pavlou, P. A., \& El Sawy, O. A. (2011). Understanding the elusive black box of dynamic capabilities. Decision Sciences, 42(1), 239-273.

Porter, M. (1985). Competitive advantage. Free Press, New York.

Ragin, C. C (2008). Redesigning social inquiry: Fuzzy sets and beyond. University of Chicago Press.

Richard, C. M. Y., William, L., Esther, P. Y. T., \& Antonio, K. W. L. (2011). Analysis of sources of innovation, technological innovation capabilities, and performance: An empirical study of Hong Kong manufacturing industries. Research Policy, 40(3), 391-402.

Saunila, M., Pekkola, S., \& Ukko, J. (2014). The relationship between innovation capability and performance the moderating effect of measurement. International Journal of Productivity and Performance Management, 63(2), 234-249.

Skarzynski, P., \& Gibson, R. (2008). Innovation to the core: A blueprint for transforming the way your company innovates. Harvard Business School Press, Boston.

Steenkamp, J., \& Van Trijp, H. (1991). The use of LISREL in validating marketing constructs. International Journal of Research in marketing, 8(4), 283-299.

Suarez-Villa, L. (1990). Invention, inventive learning and innovative capacity. Behavioral Science, 35(4), 290310.

Tseng, S. M., \& Lee, P. S. (2014). The effect of knowledge management capability and dynamic capability on organizational performance. Journal of Enterprise Information Management, 27(2), 158-179.

Wang, C. L., \& Ahmed, P. K. (2007). Dynamic capabilities: A review and research agenda. International Journal of Management Reviews, 9(1), 31-51. 
Wernerfelt, B. (1984). A resource-based view of the firm. Strategic Management Journal, 5(2), 171-180.

Woodside, A. G. (2013). Moving beyond multiple regression analysis to algorithms: Calling for adoption of a paradigm shift from symmetric to asymmetric thinking in data analysis and crafting theory. Journal of Business Research, 66(4), 463-472.

Zahra, S. A., \& George, G. (2002). Absorptive capacity: A review, reconceptualization, and extension. Academy of Management Review, 27(2), 185-203. 